Jill A. Grunenwald

\title{
Orange is the new academia How my experience as a prison librarian enriches my approach as an academic librarian
}

came to academic librarianship after a two year stint behind bars.

Allow me to rephrase: For the past three years I have been employed as the librarian at a small career college on Cleveland's east side. Prior to that, my first professional job right out of graduate school was the sole librarian at an all-male, minimum-security prison on the far west side of the city.

For 21 months, I had the opportunity to work directly with a service population unlike any I had ever seen before or probably will ever see again and I loved the daily interactions with inmates. I notarized documents, provided information about Ohio University's College for the Incarcerated Program, delivered recreational reading material to the segregation unit, and kept the law library current. Twice I was interviewed for "The Yard" - the monthly newsletter written by inmates in the computer class-and was known simply as Ms. G (G as in "Gangsta"). In my role as the librarian, I was witness to personal stories that both broke and lifted my heart in equal measure.

When I first began working at the college, I assumed my days as a prison librarian would merely serve as entertaining anecdotal stories. Instead, I have found that my time spent behind bars prepared me in unexpected ways for the day-to-day situations that occur in an urban academic library.

Because of our location, we often work with members of Cleveland's underprivileged population who share similar backgrounds to the inmates I had previously assisted. In a 2013 article discussing the beneficial partnership between public and prison libraries, correctional librarian Daniel Marcou says, "Freedom is probably the most valued word inside a corrections facility. I wanted to convey to the residents that reading and information can help to free us all from our past or places where we might not want to be in life. And the ticket, of course, is a library card." ${ }^{1}$ For our students, the decision to come to school is not taken lightly and is frequently seen as an opportunity to change their path and better their life.

1. Check your privilege at the door. Every day I arrive to work with an advanced degree and many years learning at multiple institutions of higher education. I also was raised in an upper middle class community, and by the time I was in fifth-grade in the early 1990s, we already had computers in our classrooms. Many of the students I work with every single day arrive to their initial admissions meeting with a GED and are first generation college students. I see the digital divide every single day just as I did at the prison, where many of the inmates chose to use the typewriter and physical collection

Jill A. Grunenwald is librarian at Remington College, e-mail: jillgrunenwald@gmail.com

(c) 2014 Jill A. Grunenwald 
for their legal research because it was less overwhelming than attempting to navigate the word processor and Lexis Nexis. Simple tasks I take for granted prove frustrating to a student with limited computer skills, and it's my job to help them grow their knowledge base in the technological age.

2. Earn respect, don't demand it. In a prison, the guards who expect their uniform and badge to be enough to command obedience tend to be the ones the inmates respect the least. Likewise, I can't walk into a classroom to give an information literacy presentation and expect the students to listen to me just because I happen to be the person standing at the front of the room. The students respond best to staff members who treat them as peers with the understanding that everyone has the common goal of making sure they are given the best education possible. By setting that foundation at the very beginning, when it becomes necessary to step in with a more authoritative role, the student will be more likely to listen if they appreciate that you are providing this information as a means of reaching that goal.

3. Meet them on their level. One afternoon an inmate came in wanting a book to read. Back in high school he had skipped out on all required reading and now that he was left with lots of time on his hands decided to put it to good use. I pulled out a copy of The Great Gatsby and suggested he start with that. When he asked me what it was about, I paused for a minute and said, "Well, it's about a gangster." A simplistic interpretation of Jay Gatsby, yes, but I knew my service population well enough to know what would resonate and what wouldn't. Within a week the inmate was back in the library looking for another book just like that one.

It's often easy for us to slip into librarian jargon when explaining something to a student but sometimes the most effective way to increase their comprehension of a subject is to abandon the technical terminology. This does not mean talking down to them but, instead, reframe it in terms that better fit their own life experiences.
4. Importance of personable public services. At both the prison and my college, I'm the only librarian, so I can't exactly spend my day hiding in my office. In prison, life threatening instances can and would happen if staff members weren't paying attention so I'm familiar with the importance of making sure my patrons are constantly aware of my presence. But, more than that, not only is it paramount that the students know I'm available, they need to know I'm approachable, as well. An unfriendly librarian benefits no one, and if that is the only library encounter a user has, it may negatively color their view of all libraries and make them less likely to seek assistance when it is needed.

At both institutions, I encourage my patrons to remember that learning is a life-long endeavor, and the tools used at their current library can be transferred to the local public library when they make it back home, either because they've been released from the system or have graduated from college.

\section{Note}

1. Stephen M. Lilienthal, "Prison and Public Libraries," Library Journal 138, no. 2: 26-32. $\pi$

\section{Upcoming ACRL e-Learning}

ACRL is offering a variety of online seminars and webcasts this spring. Upcoming topics include:

Putting the User First (Webcast: June 11, 2014)

What You Need to Know about Writing Data Management Plans (Online Course: July 14-August 1, 2014)

Cultivating Creators: Copyright in the Information Literacy Classroom (Webcast: August 5, 2014)

Visit the ACRL e-Learning website at www. ala.org/acrl/onlinelearning for details. 